opt for this security rather than taking the risk associated with a private institution's higher salary. Although rarely mentioned, a substantial number of public university officials and faculty members own shares in private university companies.

The complaint most frequently heard about private universities is that their admissions standards are lower, and at first glance this would seem to be the case. University admission is based on the results of the tawjibi-the General Secondary School Certificate Examination (GSSCE). The qualifying score is 65 percent for public universities and 60 percent for private universities. Actual requirements may be higher in some specializations owing to competition. For example, medicine generally calls for at least an 85 percent score and engineering 80 percent. The GSSCE is given in subject groupings (comparable in concept to the British Alevels) but the largest category by far is the combined total in arts and science. In 1995 a total of 41,000 students took the arts exam, of whom 12,000 scored at least 65 percent and 15,000 at least 60 percent; 23,000 took the science exam, of whom 13,000 scored at least 65 percent and 15,000 at least 60 percent. (First-year places in the public universities totaled less than 15,000 that year.)

This is not the full picture, however. In the public universities about 25 percent of the available places are reserved for students in special groups who make the qualifying score (65 percent). The "special" list includes children of the armed and security forces and Ministry of Education personnel, applicants from certain foreign countries (not including Malaysia, which has its own separately negotiated quota), and those with wasta of one kind or another. This exemption means that the sliding scale of competition does not affect a large number of applicants, and consequently many better qualified students lose their public university slots to the less qualified.

\section{Problems and Solutions}

The basic problem of private higher education in Jordan is that the private universities were established as a "quick fix" for the mushrooming access deficit in a system without surplus money, and where the existing money was not effectively spent. Furthermore, the development of the private university was restricted to the existing tradition in curriculum and delivery rather than reaching out for innovation and creativity.

Recent weeks have seen public addresses given by Crown Prince Hassan, Princess Sarvath, and others signifying potential changes. Probable actions are: professionalizing the Higher Education Council and adding private university representation, improving the management autonomy of both private and public institutions, and establishing an accreditation body for all higher education. With these first steps taken, the private universities may be able to cross the threshold into a new importance in Jordanian higher education.

\section{Private Higher Education in Pakistan: The Need for Order}

\section{James Coffman}

James Coffman is executive director of the U.S. Educational Foundation in Pakistan. Address: USEF/P, P.O. Box 1128, Islamabad, Pakistan.

W ith the creation of the state of Pakistan in 1947, only one university existed on the Pakistani side of the partition line-the University of the Punjab. In the ensuing 50 years of statehood, expanding tertiary education enrollments have outpaced the construction of new colleges and universities. Today, Pakistan has 28 public and private universities and over 100 "affiliated" or "constituent" colleges, technical training institutes, teacher training schools, and other specialized institutions. Despite a policy enacted during the Zia-ul-Haq regime in the 1980s to gradually replace English by Urdu, higher education continues to be conducted mostly in English.

In the early 1970s, education was nationalized under the Bhutto regime, effectively ending private education in Pakistan. Grants for funding universities were dispensed by each province. In 1979, the federal government assumed control over all university grants, ensuring a centralized administration of the country's university system. Today, 67 percent of all public university income comes from these federal grants. Additionally, all appointments of faculty and administrators are made by the Ministry of Education, thereby depriving universities of any autonomy whatsoever. In the mid-1980s, private educational institutions were again allowed to operate, on the condition that they uphold standards.

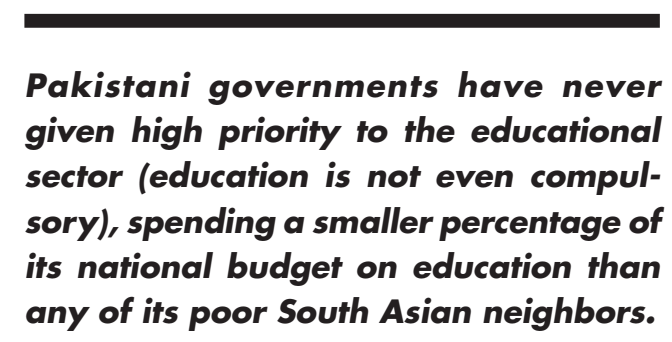

While the state has assumed increasingly greater control over the financing and administration of higher education through the years, the country has been rocked by severe political upheaval and economic decline. Successive governments have failed to impose an acceptable rule of law within the country. The lawlessness, corruption, nepo- 
tism, and intense intergroup conflict of Pakistani society have become a part of the higher education system as well.

Pakistani governments have never given high priority to the educational sector (education is not even compulsory), spending a smaller percentage of its national budget on education than any of its poor South Asian neighbors. This is further exacerbated by the ongoing decline of the economy. The result has been a grossly underfunded public higher education system unable to pay decent salaries, maintain libraries, purchase minimal supplies, or even keep physical facilities from crumbling. Student and faculty morale is extremely low. Research is practically nonexistent. Class schedules are frequently not respected, and the academic year is regularly disrupted by myriad political and administrative conflicts. There is a near unanimity among Pakistanis that the nation's public higher education system is a disaster.

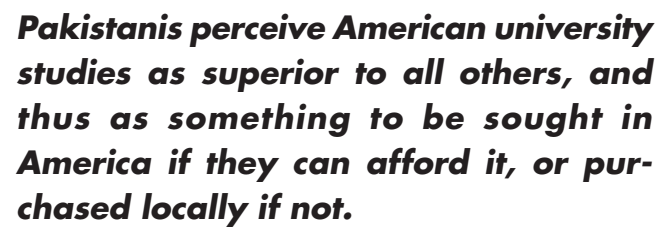

Nevertheless, the number of young people seeking higher education continues to grow sharply each year, as the return on university studies is still quite high. With the state incapable of keeping pace with this growth-coupled with a national policy to stimulate the Pakistani private sector-the government has tacitly allowed the private higher education system to expand with minimal oversight. Six new universities have recently been awarded charters by the Ministry of Education, with another six under review. Bright spots in this booming private sector are institutions such as the Aga Khan University and Hamdard University in Karachi, and the Lahore University of Management Sciences in Lahore. They offer high-quality instruction and excellent facilities, albeit at rates that few Pakistani families can afford. But many other private institutions have been opened that have not come under the purview of any official body and that violate basic ethical, if not legal, standards in attracting their paying customers. Indeed, many private institutions are now exhibiting free-wheeling, unregulated, and brazen market tactics, where corruption, smuggling, counterfeiting, and trademark infringement are the rule.

Pakistanis perceive American university studies as superior to all others, and thus as something to be sought in America if they can afford it, or purchased locally if not.
With the growing disaffection with the public system, the upper classes able to afford the $\$ 500$ to $\$ 3,000$ annual tuition are flocking to the local American alternatives. In the last five years, a hodgepodge of private institutions has arisen that bill themselves as full-fledged, accredited, branch American universities, or as affiliated with American universities and awarding degrees from their American affiliate. The majority of these claims are fraudulent, underlining their "foreign-trained" faculty as a guarantee of quality.

Pakistanis are ill-equipped to evaluate such claims and generally assume that American universities are worthy of their trust. The "American" degree they receive is assumed to guarantee international recognition and access to higherlevel studies anywhere in the world. Some local institutions are working in conjunction with accredited American universities that have opted to sell their names and their degrees for fairly lucrative returns. Other institutions are simply groups of investors who have obtained business licenses in Utah, Iowa, Hawaii, etc., under the name of "University of . ..," and who then open up their schools in Pakistan as "off-shore" operations. Still others are merely bogus schools in rented facilities that claim affiliation with nonexistent, but American-sounding, universities. Faced with court challenges as to the legality of their operations, some have simply informed the court that as "American" universities, they are not obliged to abide with Pakistani regulations.

While the existence of "pirate" universities and multinational diploma mills is a worldwide phenomenon, the magnitude of the problem in Pakistan has led the University Grants Commission to consider, rightly, that these institutions constitute a threat to higher education. Because increasing numbers of graduates of questionable institutions now are requesting official recognition of their degrees to take government jobs, UGC bureaucrats have come under strong pressure from influential groups to do so.

\section{While the existence of "pirate" univer- sities and multinational diploma mills is a worldwide phenomenon, the magni- tude of the problem in Pakistan has led the University Grants Commission to consider, rightly, that these institutions constitute a threat to higher education.}

The growth of private higher education has had some positive impacts. Private universities generally pay much higher salaries, and the best ones offer quality libraries and research facilities. They tend to respond to the public's de- 
mand for modern, hands-on, practical training in business and technology majors. The schools are free to offer innovative curricula, unconstrained by bureaucratic demands to adhere to an outdated, set program. They usually offer more appealing learning environments that are free of political conflict and physical decay. And they have caused public universities to take a closer look at their own responsiveness to the needs of students and the market. The top public university, Quaid-i-Azam University in Islamabad, while ensuring merit-based access and virtually free education for most students, has enacted a policy of setting aside a quota of places in its MBA program for students paying full tuition (over $\$ 1,200$ per year) in order to increase revenue. This will probably result in a greater effort to raise standards and make the program competitive with the top private ones. This scheme is being offered at the International Islamic University as well, and will be introduced in other public universities throughout the country.

\section{The rise of private education in coun- tries such as Pakistan, where the state is unable to provide and regulate ad- equate social services and to oversee the functioning of the market, is cer- tainly a two-edged sword.}

The rise of private education in countries such as $\mathrm{Pa}$ kistan, where the state is unable to provide and regulate adequate social services and to oversee the functioning of the market, is certainly a two-edged sword. Will the current anarchic and exploitative nature of much of private higher education be stemmed by legal constraints and weeded out by market forces and be replaced by a quality option that will also stimulate the public institutions to needed reform? Or will it deepen the frustration of most Pakistanis seeking higher education who are disillusioned with public education, but who see the quality option as the privilege of the wealthy? In Pakistan, the future of private higher education will depend on the existence of a strong state dedicated to maintaining social, economic, and political order.

\section{Internet Resource}

For more information on international issues in higher education, visit the Center's web site, located at:

http://www.bc.edu/bc_org/avp/soe/cihe/

\section{Private Higher Education in Hungary}

\section{Judit Nagy-Darvas}

Judit Nagy-Darvas is a research fellow at the Hungarian Institute for Educational Research. Address: Hungarian Institute for Educational Research, Budapest, Verhalom u. 18/a H-1023, Hungary.

\section{Introduction}

Tn recent years, Hungarian higher education reform has 1 focused on one basic objective: the shift from a reliance on central planning to a system characterized by more effective mechanisms of serving social (e.g., unemployment and a population with new skills and ways of thinking about the world) and economic needs (an emerging market economy). Expansion in student volume has been a priority in this effort.

Prior to 1989, Hungary's higher education system was small and elitist. Today, among European Economic Community (EEC) countries, Hungary's aggregate student population has experienced one of the largest expansions of the last decade. The number of full-time students has doubled, from 64,000 to more than 140,000 , a figure representing only 16 percent of the 18 -to-22 age group (as the system cannot admit even half of its applicants).

The growth of private higher education in Hungary is an important element in the effort to train students in fields now greatly in demand. Also, the private sector is expected to help achieve national targets for increased enrollments, but without a concomitant increase in state support.

\section{Among the 33 nonstate higher educa- tion institutions, 5 universities and 23 colleges are church owned, and five colleges were established through pri- vate foundations.}

\section{Private-Sector Characteristics}

Among the 33 nonstate higher education institutions, 5 universities and 23 colleges are church owned, and five colleges were established through private foundations. Despite the relatively small size of the nonstate higher education sector and some regulatory constraints on development, its enrollment has increased significantly during the last three to four years. The total number of students in nonstate higher education is around 25,000 at present, a number representing nearly 12 percent of total student 